\title{
Multimedia Quake Poetry: Convergence Culture after the Sichuan Earthquake
}

\author{
Heather Inwood ${ }^{*}$
}

\begin{abstract}
This article examines a wave of Chinese poetry sparked by the 2008 Sichuan earthquake. "Quake Poetry" was published online before being re-circulated through digital, print and live media. Multimedia adaptations of one poem are examined to investigate the relationship between the authors of Quake Poetry, the different media platforms, and the people and institutions involved in its proliferation. Media convergence enabled Quake Poetry to fulfil several functions in the aftermath of the earthquake. Most prominently, it served as an emotional outlet for those affected by the quake, while giving its netizen-producers a sense of creative agency as they engaged in participatory cultural production. Members of the contemporary poetry scene cited Quake Poetry as evidence of poetry's ongoing hold over the Chinese national consciousness. Finally, certain poems were appropriated and promoted by China's state-controlled media to propagate a politically expedient image of Chinese unity in the face of tragedy.
\end{abstract}

Keywords: Sichuan earthquake; multimedia poetry; internet; contemporary poetry scene; trauma process; convergence culture

The Sichuan earthquake of 12 May 2008 has been widely cited as a catalyst for the growth of Chinese civil society, as well as for an upsurge in patriotism and national unity centred around traditional Chinese virtues. ${ }^{1}$ The role played by new media in reporting and documenting the earthquake has also been noted. ${ }^{2}$ Reactions among the Chinese public included a wave of poetry composition

* Ohio State University, Columbus. Email: inwood.4@osu.edu

1 For an assessment of how the earthquake may have contributed to China's growing civil society see Jessica C. Teets, "Post-earthquake relief and reconstruction efforts: the emergence of civil society in China," The China Quarterly, No. 198 (2009), pp. 330-47. For an account of the earthquake and traditional Chinese virtues see Hua Zhishu, "Wenchuan dizhen jiuzai yu chuantong meide" ("Wenchuan earthquake relief and traditional virtues"), http://huazhishu.blog.sohu.com/88906468.html. For a typical Western journalistic account see Jonathan Watts, "Sichuan earthquake: tragedy brings new mood of unity," The Guardian, 10 June 2008, http://www.guardian.co.uk/world/2008/jun/10/chinaearthquake. china. All websites cited in this article accessible as of 20 May 2010.

2 See e.g. George Haddow and Kim Haddow, Disaster Communications in a Changing Media World (Oxford: Butterworth-Heinemann, 2008), pp. 35-36; "Sichuan earthquake and its aftermath," Socialtext, http://www.socialtext.net/cdt/index.cgi?sichuan_earthquake_and_its_aftermath; and Yang Guobin, "Sichuan earthquake and relief efforts: the power of the internet," EAI Background Brief No. 389, http://www.eai.nus.edu.sg/BB389.pdf. 
that swept across the country in the days and weeks after the earthquake hit. “Quake Poetry" (dizhen shi 地震诗), also named "Quake Resistance Poetry" (kang zhen shi 抗震诗) or “Wenchuan Poetry” (Wenchuan shige 汶川诗歌) after the town at the epicentre of the quake, refers to any poem written in reaction to the earthquake, as well as to the phenomenon of Chinese people turning to poetry as an emotional outlet. This is a tradition that finds modern precedent in China in the Multimillion Poem Movement of the Great Leap Forward (1958-61) and the Tiananmen Poetry of 1976. Beginning the day after the quake, linear text poems were posted in their hundreds and thousands on internet forums and blogs, and sent around by email and text message. ${ }^{3}$ They were soon reproduced nationwide in newspaper columns, published in print anthologies, recited on radio and television, and performed at poetry recitals and charity events. ${ }^{4}$ Multimedia versions were posted online, featuring music, voice, photographs and video footage. Although well-known poets also composed works in response to the earthquake, the most widely-circulated Quake Poems were produced by so-called “ordinary netizens" ( putong wangmin 普通网民), who were reported to have barely written a poem in their lives. ${ }^{5}$ In China, Quake Poetry was to become one of the most talked-about cultural phenomena of 2008, an event which spoke not just to the enduring popular appeal of this literary genre, but also to the evolving relationship between culture, politics and media in the contemporary PRC.

This article examines the uses of different media in the production, circulation and consumption of Quake Poetry, and the discourses invoked in media coverage and online discussions of these poems. It will show how Quake Poetry emerged through a convergence of digital, print and live media, enabling it to spread rapidly throughout mainland China and beyond, in the process satisfying the various narratives of the individuals and institutions involved in its production, circulation and consumption. I begin by looking at the explicit and implicit connections made by commentators between Quake Poetry and other mass poetry movements of China's past. After a brief overview of typical Quake Poems, the main analysis focuses on a poem initially posted and circulated anonymously online, entitled "Child, quickly grab hold of Mama's hand" (Haizi, kuai zhuajin

3 According to several articles, the chat room of one Chinese website experienced an influx of over 15,000 poems on 19 May alone. See e.g. Wang Gan, 'Zai feixu shang chuli de shige jinianbei: lun '5.12' dizhen shichao" ("A poetry memorial standing tall above the ruins: on the "12 May' poetry tide"), http://whj. smx.gov.cn/ReadNews.asp?NewsID=3871.

4 For more on print collections of Quake Poetry see Lin Meng, "Wenchuan dizhen shige shubaokan shoucangjia Jiang Hongwei" ("Collector of Wenchuan quake poetry books, newspapers and magazines Jiang Hongwei”), http://www.xshdai.com/wenku/20090302/16566.html.

5 Cf. Chen Hongli, "Shi shen zai feixu shang gechang: you 'Wenchuan shichao' tan dizhen shichao de yiyi he qishi" ("The god of poetry sings in the rubble: from 'Wenchuan poetry' to thoughts about the meaning and revelations of the earthquake poetry tide"), http://blog.sina.com.cn/s/blog_4868bcc80100dgdp. html; Pang Chunjie, "Su Shansheng: wo zhibuguo shi luguo de daibizhe" ("Su Shansheng: I was just a passing ghostwriter"), http://dzrb.dzwww.com/dazk/dzzm/200805/t20080530_3651395.htm; Chen Yunfa, "Wangping: kang zhen, rang shige fusu" ("Web comments: earthquake relief efforts, bringing recovery to poetry"), http://opinion.people.com.cn/GB/7384308.html. 
mama de shou 孩子, 快抓紧妈妈的手), as well as multimedia adaptations of the poem. Despite certain variations between these adaptations, all feature similar visual, oral and textual tropes that point to a convergence of interests among the poem's producer(s), the mass media and the central Chinese government.

My discussion borrows from the work of media studies scholar Henry Jenkins to propose that Quake Poetry can be seen as part of an emerging convergence culture that is being born from a combination of technological development and socio-political transformation in contemporary China. Examining the production, circulation and adaptation of these poems reveals how convergence took place on multiple levels: between media technologies, among producers and consumers (or what some call "prosumers" 6 ), and between different interest groups. Ultimately, Quake Poetry aided not only in what Jeffrey Alexander terms the trauma process, ${ }^{7}$ that is to say an imaginative representation of trauma that allowed the Chinese people to grieve en masse, and to experience through poetry a form of cathartic release within politically approved limits. It also promoted a politically expedient image of national unity in the face of adversity, which extended beyond the borders of the PRC and gained favour in international media discourse on the Sichuan earthquake.

\section{Quake Poetry: Chinese Media Discourse and Archetypal Examples}

News articles written on the Quake Poetry phenomenon focused on the diversity and numbers of people writing poems in response to the earthquake, the large volume of Quake Poetry anthologies published in May 2008, and the emotional effects of these poems, "consoling those who lost relatives in the disaster, inspiring those helping in rescue efforts, and eulogizing the fortitude shown by Chinese people in times of great calamity." 8 Some exclaimed "the entire population writes poetry" (quanmin xie shi 全民写诗), a phrase used in 2006-07 in reference to the online spoofing of the poet Zhao Lihua 赵丽华9; others used the designation “earthquake poetry transcriptions" (dizhen shichao 地震诗抄).

Whereas the phrase "Quake Resistance Poems" implies a narrative of national unity with the Chinese people coming together to "resist" the disaster as if resisting a common wartime enemy, "transcriptions" (chao 抄) resonates rather with mass literary movements like the Tiananmen Poetry (Tiananmen shichao 天安门诗抄) of April 1976. Following Zhou Enlai's death on 8 January that year, thousands

6 Yu Haiqing, Media and Cultural Transformation in China (London \& New York: Routledge, 2009), p. 11. The term "prosumer" was first coined by Alvin Toffler in his book The Third Wave (New York: Morrow, 1980).

7 Jeffrey C. Alexander, Cultural Trauma and Collective Identity (Berkeley: University of California Press, 2004).

8 Jiang Xiaoling, “Dizhen shichao' rang shige chonghui minjian” ("Earthquake poetry transcriptions, returning poetry to the folk"), http://news.xinhuanet.com/book/2008-06/04/content_8310692.htm.

9 Zhao was spoofed by netizens for writing colloquial poems that were deemed so simple that anyone could produce them simply by repeatedly hitting the "return" key on their computer; this despite her being a "national first-level poet" (guojia yiji shiren), a title gained by way of literary awards and membership of the Chinese Writers' Association. 
of poems were composed by ordinary Chinese people, displayed in locations in and around Tiananmen Square, copied down and circulated by hand, and recited aloud and turned into songs, before being published in print anthologies in 1977-79. ${ }^{10}$ Although ostensibly written to mourn the passing of Zhou, the contents of Tiananmen Poetry touched upon a widespread discontent with the Chinese leadership of the time. ${ }^{11}$ Several Chinese news articles published in May 2008 directly compared Quake Poetry to Tiananmen Poetry. This comparison not only emphasized the continued hold of poetry over the Chinese national consciousness, ${ }^{12}$ but also hinted at an analogy between both events regarding the power of the masses to forge their own emotional and cultural responses to major events.

Commentators drew a further historical parallel between Quake Poetry and the Multimillion Poem Movement (baiwan shige yundong 百万诗歌运动, also known as the New Folksong Movement xin min'ge yundong 新民歌运动) of the Great Leap Forward. ${ }^{13}$ News reports on the volume of Quake Poems circulated online recall government orders issued in 1958 to work units across China to produce poetry in support of the communist revolution, and the subsequent hyperbole used by the CCP to publicize the numbers of poems being written. ${ }^{14}$ Great Leap Forward poems were so numerous that they were counted using basketfuls (lü 管) or carloads (che 车) instead of the usual pieces (shou 首). ${ }^{15}$ Similarly, it is the volume of poetry produced in response to the Sichuan earthquake rather than the quality of individual pieces that has impressed commentators. ${ }^{16}$ The Quake Poem discussed below does not stand out as unusual, or unusually well written. It has been taken, rather, as an example of the "direct mass appeal"17 of such poetry. It is, furthermore, evidence of the facilitating power of new media technologies to send an individual cultural text on a fast track to the national psyche, blurring boundaries between producers and consumers, and institutional and vernacular interests. ${ }^{18}$

10 Tiananmen shichao (Tiananmen Poetry Transcriptions) (Beijing: Renmin wenxue chubanshe, 1978).

11 Bonnie McDougall and Kam Louie, The Literature of China in the Twentieth Century (New York: Columbia University Press, 1999), pp. 424-25.

12 "Xinwen wubao: cong 'dizhen shi' zouhong xiangdao shige chulu" ("Noon news: the popularity of 'quake poetry' points to the way out for poetry"), http://ent.sina.com.cn/r/m/2008-06-05/09592049313. shtml; Wang Gan, "A poetry memorial standing tall above the ruins"; Tu Guowen, "Kang zhen shige: Zhongguo dangdai shige yundong de di san ci langchao" ("Anti-quake poetry: the third wave contemporary Chinese poetry movement”), http://cache.tianya.cn/publicforum/content/no16/1/138874. shtml; and Jiang Yunfan, "Lun 'Wenchuan shige' xianxiang" ("On the 'Wenchuan poetry' phenomenon"), http://www.shigebao.com.cn/redirect.php?fid=9\&tid=266971\&goto=nextoldset.

13 Ling Hongfa, "Kang zhen shige: minzu beiqing de yishihua biaoda" ("Quake relief poetry: the ritualized expression of national sorrow"), in Xinmin wanbao (New People Evening News) 14 June 2008; also online at http://news.xinmin.cn/opinion/lxpl/2008/06/14/1192730.html; and Tu Guowen, "Anti-quake poetry."

14 S.H. Chen, "Multiplicity in uniformity: poetry and the Great Leap Forward," The China Quarterly, No. 3 (1960), p. 1.

15 Ibid. p. 7.

16 For an example of the rhetoric of numbers see Gan Tianquan, "Zhenhan linghun de chongjibo: dizhen shichao de dongyin yu qishi" ("A wave that shook the heart: the causes and inspirations of the quake poetry tide"), Dangdai wentan (Contemporary Literature Scene), No. 4 (2008).

17 Chen, "Multiplicity in uniformity," p. 8.

18 Robert Glenn Howard, "Electronic hybridity: the persistent process of the vernacular web," Journal of American Folklore, Vol. 121 No. 480 (2008), p. 194. 
Before looking at the poem "Child, quickly grab hold of Mama's hand," it is worth examining some different examples of Quake Poetry. The following is typical of works that were circulated anonymously online by netizens. It is called “China! Don’t cry” (Zhongguo! Bu ku 中国! 不哭), and the author's name appears to have been lost - some websites carry the IP address used to post the poem in place of the author's name or web ID. ${ }^{19}$ Here is the first section:

China! Don't cry!

Chinese people! Don't cry!

When the Olympic torch met with humiliation we pursued justice with no turning back!

When wind and snow cut off the roads home we protected each other!

When the train sped off the tracks we helped each other with all our hearts!

When sickness swallowed lives we made up for them with love!

When tremors split the land we divided the mountains and opened roads!

China! Don't cry!

Chinese people! Don't cry!20

This poem is first and foremost a paean to the spirit of the Chinese people, and their ability to unite in overcoming perilous circumstances; it refers to other 2008 disasters that preceded the Sichuan earthquake, including the Olympic torch protests, the January snowstorms and the fatal train crash in Shandong province in April. It employs end rhyme throughout based on the word “cry” ( $k u$ 哭), and contains an abundance of exclamation marks and patriotic images like the sun, the red flag and the hands of the masses, making the poem reminiscent of Great Leap Forward or Cultural Revolution era literature. Other similar poems include “Together in life and death" (Shengsi bu li 生死不离) written by Beijing Olympics committee member Wang Jiuping 王久平 (not technically a "netizen" because of his official affiliations), "Passionately love life" (Re'ai shengming 热爱生命), and “Ode to peace” (Ping'an song 平安颂). ${ }^{21}$

Early responses to the earthquake among mainland China's unofficial ( $f e i$ guanfang 非官方) or avant-garde (xianfeng 先锋) poetry scene are also worth a brief overview here. The avant-garde poetry scene, which has its roots in underground literature of the Cultural Revolution, is distinguished by its ideological, institutional and aesthetic separation from mainstream literary production. ${ }^{22}$ This involves a rejection of - and often by - both orthodox literary channels, which are the most subject to the Chinese central government's ideological agenda and censorship mechanisms, and commercial publication, which is

19 See e.g. the following Sina news report posted on 16 May 2008: http://news.sina.com.cn/c/2008-05-16/ 061515550279.shtml.

20 "Wenchuan dizhen shichao zhi er" ("Wenchuan quake poetry transcripts No. 2"), http://www.bdsz.com/ Article_Show.asp?ArticleID=1421.

21 Ibid.

22 Maghiel van Crevel, Poetry in Times of Mind, Mayhem and Money (Leiden: Brill, 2008), p. 6. Van Crevel suggests that use of the term "avant-garde" has aesthetic implications, whereas "unofficial" suggests an institutional distinction. For the sake of simplicity I use the term "avant-garde" to refer to the contemporary poetry scene that sees itself as distinct from both the orthodox literary establishment and the "masses" of netizens, who turn to poetry only when occasion requires or inspires. 
motivated primarily by profit and thus rarely interested in the works of China's experimental and independent-minded poets. This dual separation has led to depictions of the avant-garde poetry scene as highly marginalized (bianyuanhua 边缘化). It has also resulted since the early 1990s in the formation of a crisis discourse among Chinese poets and critics, who make regular doom-laden predictions of poetry's declining position within contemporary culture, or even imminent "death." 23 Scholars including Maghiel van Crevel have pointed out that such depictions are little more than "socio-economic reductionism," which ignore the broader socio-cultural relevance and artistic achievements of contemporary poetry beyond the size of its readership and financial revenue. ${ }^{24}$ In short, although the avant-garde poetry scene may be described as a fairly typical case of "production for producers" 25 that only rarely attracts the attention of people outside the scene, it nevertheless constitutes a lively, active and highly networked field of literary production.

Unlike the largely anonymous netizen authors of Quake Poems, avant-garde poets wrote nonymously as poets of varying levels of renown. Some poems penned by self-professed members of the avant-garde demonstrated marked differences from those examined thus far. The following work was posted on 24 May 2008 on the online poetry forum Poetry Vagabonds (Shi jianghu 诗江 湖), the home of poets aesthetically aligned with the now-defunct Lower Body (xia ban shen 下半身) poetry group. ${ }^{26}$ It is written by the poet $\mathrm{Gu} \mathrm{He}$ 古河 and is entitled "After the earthquake was over, I admit" (Dizhen guo hou, wo chengren 地震过后, 我承认). ${ }^{27}$ The final section reads as follows:

I admit

I didn't cry

I didn't donate

I didn't pray either

all that time I was worrying about getting that job

all that time thinking about how to chat up the girl who works in the supermarket and how to earn enough cash to buy that new complete set of works by Borges but I'm still a person too

The poem requires little in the way of interpretation: the narrator makes the guilty admission of having put quotidian concerns before grief or philanthropy, yet refuses to believe this behaviour makes him less of a human being. In general, avant-garde poetry forums witnessed a wider range of emotional, intellectual and

23 For more on the crisis discourse see ibid. pp. 32-33. For an example of this kind of Chinese critical writing see Ma Ce, "Shige zhi si" ("The death of poetry"), in Tan Wuchang (ed.), Zhongguo xinshi baipishu 1999-2002 (Beijing: Kunlun chubanshe, 2003), pp. 514-24.

24 Van Crevel, Poetry in Times of Mind, Mayhem and Money, pp. 48-49.

25 Ibid. p. 35.

26 For more on the function of avant-garde online poetry forums see Michel Hockx, "Virtual Chinese literature: a comparative case study of URL poetry communities," The China Quarterly, No. 183 (2005), pp. 670-91, and Heather Inwood, "Identity politics in online Chinese poetry groups," Postmodern China (Berliner ChinaheftelChinese History and Society), No. 34 (2008), pp. 77-94.

$27 \mathrm{Gu} \mathrm{He}$, "Dizhen guo hou, wo chengren" (“After the earthquake was over, I admit”), http://my.clubhi. com/bbs/661502/18/97465.html. 
verbal responses than the netizen-penned Quake Poems discussed so far, including anger, provocation, profanity and black humour. Some poets objected outright to the existence of Quake Poetry, arguing that a more natural reaction to the tragedy would be creative silence. The poet, critic and scholar Zhou Zan 周珗 pointed out that most Quake Poetry had unconsciously adopted a Scar Literature (shanghen wenxue 伤痕文学) style, implying it had placed knee-jerk emotional catharsis before literary sophistication, ${ }^{28}$ and expressed disagreement with claims that the earthquake had given rise to "poetry fever" (shige re 诗歌 热). ${ }^{29}$ The literary critic and scholar Xie Youshun 谢有顺 remarked that as time passes and the earthquake is forgotten, poetry too will probably "return to its original [marginalized] state," and thus Quake Poetry cannot be considered evidence of a widespread poetic renaissance. ${ }^{30}$

Despite such voices of caution, the majority response to the earthquake amongst the contemporary poetry scene can be summarized as one of support, and poets expressed hope that their work could aid in fundraising movements and console the people of China. ${ }^{31}$ Numerous critics wrote favourably of the phenomenon, equating it with trends in poetry production referred to as "grassroots poetry" (caogen shige 草根诗歌), ${ }^{32}$ and seeing it as evidence of a newly liberal atmosphere in mainland China regarding poets' freedom to respond to events of national significance. ${ }^{33}$ Quake Poetry confirmed the significance of poetry as an art form in modern China, provided publishing opportunities, and invigorated discussions within the poetry scene about contemporary poetics. Although there was a high level of disagreement amongst poets and critics regarding its long-term impact on the

28 Scar Literature, a literary movement that emerged with the end of the Cultural Revolution and new political relaxations regarding acceptable literary content, has been criticized for being formulaic and didactic: see Deirdre Sabina Knight, "Scar literature and the memory of trauma," in Joshua S. Mostow (ed.), The Columbia Companion to Modern East Asian Literature (New York: Columbia University Press, 2003), pp. 527-32.

29 Zhou Zan, "Da dizhen yu wenxue biaoda" ("The big earthquake and literary expression"), http:// mythicizer.ycool.com/post.2880492.html.

30 Pu Lizi, "Xie Youshun: shige yinggai yu shidai gandan xiangzhao" ("Xie Youshun: poetry should be in tune with the times"), http://news.sina.com.cn/c/2008-06-01/081615659442.shtml.

31 See e.g. "A proposal to all of China's poets from the website Poemlife and the journal Poetry and People," http://www.poemlife.com/PoemNews/news.asp?vNewsId=4008, in which the editors describe plans to hold fundraising poetry recitals in cities throughout Guangzhou province, and request that poets write earthquake-themed poems to be recited at these events. Similar recitals were held across China, and most regions published their own volume of Quake Poetry.

32 Pu Lizi, "Xie Youshun: poetry should be in tune with the times," and "Caogen shige jujiao Wenchuan dizhen" ("Grassroots poetry focuses on the Wenchuan earthquake"), He'nan ribao, 29 May 2008, http:/l newpaper.dahe.cn/hnrb/html/2008-05/29/content_69970.htm. For more on grassroots poetry see Wu Sijing, "Mianxiang diceng: shijichu shige de yi zhong zouxiang" ("Facing the lower rungs: one direction in poetry at the beginning of the new century"), http://www.gzwhys.com.cn/node_162/node_165/ node_343/2006/11/07/11628855834141.shtml, and Li Shaojun, "CCaogen xing' zhengzai shige zhong kuosan: da 'Shenzhen shangbao' jizhe wen" (“'The essence of grassroots' is spreading in poetry: in response to questions from a reporter from 'Shenzhen business news"'), http://www.wyzxsx.com/ Article/Class 12/200711/28103.html.

33 Jiang Yunfan comments, for example, that it would have been impossible for anyone to write and publish avant-garde poetry in response to the Tangshan earthquake of 1976, which killed around a quarter of a million people but was subject to "political interference and a closed and backwards social environment" within China. Jiang Yunfan, "On the 'Wenchuan poetry' phenomenon." 
development of contemporary Chinese poetry, most observers were able to describe the phenomenon in a way that met their own pre-existing narratives concerning the position and ideal role of modern poetry in Chinese society, and how necessary it is that poets respond creatively to contemporary public events. ${ }^{34}$

\section{Child, Quickly Grab Hold of Mama's Hand}

The title of "Child, quickly grab hold of Mama's hand" is usually followed by the clause "composed for the children who died in the Wenchuan earthquake" and the date of composition, 13 May 2008. Linear text versions of the poem read more or less as follows:

Child, quickly

grab hold of Mama's hand

the path to heaven

is too dark

Mama's afraid

you'll bump your head

quickly

grab hold of Mama's hand

let Mama join you on your way

Mama

is afraid

the path to heaven

is too dark

I can't see your hand

since the fallen walls

stole away the sunlight

I'll never again see

your tender eyes

child

go now

the road ahead

has no more sadness

no more unfinished textbooks

or Papa's fists

you must remember

how Papa and I look

so in the next life we can be together again

Mama

don't worry

the path to heaven is a little crowded

there are lots of classmates and friends

we're saying

don't cry

34 For a comprehensive selection of these discussions and an overview of the different opinions expressed within the poetry scene see Huang Lihai (ed.), "5.12 Wenchuan dizhen shige xiezuo fansi yu yanjiu" ("Reflections and researches of poetic works on 12 May earthquake [sic]"), Poetry and People, No. 8 (2008). 
every child's mama is our mama

every child is Mama's child

in these days without me

give your love to those living children

Mama

don't cry

your tears won't light up

our path

let us, alone,

slowly take our leave

Mama

I'll remember how you and Papa look

I'll remember our promise

in the next life we'll be together again ${ }^{35}$

In its original form as a linear poem written in short lines with a rhyme scheme based around the word "hand" (shou 手), it is not difficult to see why this poem was a hit. Its simple, rhythmic style makes it conducive to memorization and recitation, as does the use of two voices to express the perspectives of mother and child. The tone is sad, a little sentimental, but reassuring, with the promise of reunification in the next life. In a shift of usual roles it is the child who comforts the mother, urging her to save her love for children whose lives were spared. The poem's popularity can be gauged by its publication in nearly 100 newspapers and magazines, ${ }^{36}$ its reproduction on thousands of blogs, forums and other websites, its inclusion in most officially published anthologies of Quake Poetry, and its subsequent metamorphosis into multimedia poems. ${ }^{37}$ Certain lines of the poem sound familiar to the point of cliché. An online search revealed, in fact, that the exact words of the final line, "in the next life we'll be together again," had previously featured in the lyrics to a pop song released in 1993 by the Taiwanese singer Su Rui 苏茌, entitled “Holding hands" (Qianshou 牵手). ${ }^{38}$

The widespread circulation of "Child ..." spurred a communal effort among netizens to discover the poem's original author, a process known in web slang as a "human flesh search" (renrou sousuo 人肉搜索). ${ }^{39}$ Since first being posted

35 For the Chinese version of this poem see Appendix. This translation is my own.

36 "Baozhu ni de shunjian, wo leiliu manmian: Sichuan Wenchuan da dizhen huiwang" ("The moment I held on to you tears covered my face: a look back at the massive Wenchuan earthquake in Sichuan"), http://www.sxnem.gov.cn/view.asp?ArticleID=8587.

37 A Google search of the poem's title in July 2008 resulted in 1,350,000 hits, and searches of variant titles (such as Haizi, kuai zhua ZHU mama de shou) turned up tens of thousands of results. The poem even made it in English translation on to a New York Times web page and the official blog of Jackie Chan. Cf. Andrew C. Revkin, "The road to heaven is too dark," The New York Times "Dot Earth" blog (22 May 2008), http://dotearth.blogs.nytimes.com/2008/05/22/the-road-to-heaven-is-too-dark/, and Jackie Chan, "The devastating situation in Sichuan" (14-18 May 2008), http://www.jackiechan.com/blog/ 207372-The-Devastating-Situation-in-Sichuan.

38 My thanks to Zang Di for pointing out that parts of the poem sounded remarkably similar to an old pop song by $\mathrm{Su}$ Rui.

39 For an example of a newspaper request for the author to come forward, see Wang Yuehua, "Searching for the author of the poem 'Child, quickly grab hold of Mama's hand'," posted 22 May 2008: http:/l society.news.mop.com/rw/p/2008/0522/0740368928.shtml. For usage in this instance of the term "human flesh search," see Liu Hui, "Shige 'Haizi, kuai zhuajin mama de shou' maochu duo wei 
on the Earthquake Bar (dizhen ba 地震吧) forum of baidu.com, at least six people stepped forward to claim authorship. ${ }^{40}$ Most media outlets and poetry critics concluded that the original author was a 24-year-old from Shandong province called Su Shansheng 苏善生, who was revealed to have not completed his high school education and who claimed to have only written three poems in his entire life. ${ }^{41}$

Several netizens suspected $\mathrm{Su}$ Shansheng was not the real author, expressing disgust that anyone should use "fake sentiment" to exploit the tragedy and become a celebrity. ${ }^{42}$ Such resentment may have been fuelled by Su's revelation that the poem was based on an earlier poem he had written for a deceased girlfriend, entitled "Darling, quickly grab hold of my hand" (Qin'ai de, kuai zhuajin wo de shou 亲爱的, 快抓紧我的手), which he had posted on his blog in December $2005 .{ }^{43}$ Regardless of these controversies, Su appeared well-suited to post-2000 narratives of online literary success: he is a "post-1980" (baling hou 80 后) youth with an unconventional educational background for whom blogging is second nature, much like well-known novelists Han Han 韩寒, Zhang Yueran 张悦然 and Guo Jingming 郭敬明.

The public's desire to know not just the name, but also the background, interests and personality of the author of "Child ..." contrasts with media portrayals of Quake Poetry authors as anonymous masses of "net friends" (wangyou 网友), participating in a collective cultural movement with scant thought to individual fame. It is also at odds with theories of online literary authorship, and digital cultural production more generally. As Siân Bayne suggests, a Foucauldian understanding of authorship as a socially constructed function of discourse rather than a fixed concept impervious to historical change might be most helpful to conceptualizing the creation of texts in a digital environment like the internet. ${ }^{44}$ As participatory modes of online cultural production become increasingly dominant in the 21 st century, scholars are acknowledging a shift from individual to collective understandings of authorship, and from known identities towards "ambiguous gender, geographical location and social status."45 In this case, the deployment

\footnotetext{
footnote continued
}

'zuozhe"” ("The poem 'Child, quickly grab hold of Mama's hand' gives rise to multiple 'authors"”), http://www.china.com.cn/book/txt/2008-06/02/content_15587548.htm.

40 http://www.lrn.cn/culture/whzx/200805/t20080530_236664.htm.

41 Feng Chunjie, "Su Shansheng: wo zhibuguo shi luguo de daibizhe" ("Su Shansheng: I was just a passing ghost-writer"), http://dzrb.dzwww.com/dazk/dzzm/200805/t20080530_3651395.htm, and "Benbao zhaodao 'Haizi kuai zhuajin mama de shou' shi zuozhe" ("This paper discovers the author of the poem 'Child, quickly grab hold of Mama's hand"'), Nanfang ribao (Southern Daily), http://www.nfdaily.cn/ bignews/hot/content/2008-05/25/content_4412271.htm.

42 Jiangxi yu ganhan xiao dao, "Fan Meizhong, Su Shansheng ji Furong Jiejie" ("Fan Meizhong, Su Shansheng and Sister Hibiscus"), http://cache.tianya.cn/publicforum/content/free/1/1282172.shtml.

43 Feng Chunjie, "Su Shansheng: I was just a passing ghostwriter."

44 Siân Bayne, "Temptation, trash and trust: the authorship and authority of digital texts," E-Learning, Vol. 3, No. 1 (2006).

$45 \mathrm{Ibid}$. p. 19. For an in-depth analysis of modes of online participation see Mirko Tobias Schäfer, Bastard Culture! User Participation and the Extension of Cultural Industries (The Netherlands: All Print Utrecht, 
of a human flesh search (usually reserved for cases involving "social shaming, monitoring and revenge" $)^{46}$ suggests that a significant number of Chinese netizens were invested in the issue of individual creativity, even though Su Shansheng himself claimed this to be of little importance. ${ }^{47}$ An emphasis on individual agency could help counteract the lack of control experienced by netizens when poems like "Child ..." went viral and, as demonstrated below, were adopted by the statecontrolled mass media as a symbol of the unity of Chinese people in reacting to the earthquake.

\section{Multimedia Adaptations}

By multimedia adaptations, I mean any version of "Child, quickly grab hold of Mama's hand" that includes more than just text: usually some combination of words, music, sound and images. In a three-day period of searching online, I was able to locate 20 distinct multimedia adaptations of the poem. Some are referred to as poems (shi 诗), some as songs (gequ 歌曲), some as videos (shipin 视频) and some as music videos. Although it is not always clear where these multimedia adaptations were first broadcast, published or circulated, all the versions to be discussed were uploaded online in mp4 or flash video (.flv) format on to video sharing websites including YouTube, Youku 优酷, Sina (Xinlang 新浪), Sohu (Souhu 搜狐) and others. I shall describe several examples of multimedia adaptations that differ in their use of media and attitudes towards authorship, but which demonstrate clear similarities in their deployment of certain visual, audio and textual tropes. It will be shown how, from a piece of linear text posted online, the poem quickly developed into multiple multimedia works, gaining cultural capital as it was circulated on television, recorded as pop songs, and performed at live, government-sponsored events.

The most common type of adaptation is centred upon a spoken recital of the poem. These adaptations feature some combination of journalistic photographs of the destruction caused by the earthquake, background music and subtitles carrying the text of the poem. One version features the voice of a female narrator, whose name is not disclosed. ${ }^{48}$ It is accompanied by sombre-sounding orchestral music that eventually swells into the pop song "[We don't] only love by halves" (Cai ai dao yiban 才爱到一半) by a Taiwanese girl group. The photographs are graphic, including images of corpses and parental grief. Such images, seen countless times in newspapers, on television and online in the weeks after the quake,

\footnotetext{
footnote continued

2008), available at: http://www.scribd.com/doc/8594831/Bastard-Culture-User-participation-and-theextension-of-cultural-industries.

46 Anne S.Y. Cheung, "China internet going wild: cyber-hunting versus privacy protection," Computer Law and Security Review, No. 25 (2009), p. 275.

47 Feng Chunjie, "Su Shansheng: I was just a passing ghost-writer."

48 http://www.tudou.com/programs/view/e9aDirZ3sng/.
} 
can be argued to contribute towards what psychologists term flash-bulb memories: vivid, commonly shared memories resulting from a "high level of surprise, a high level of consequentiality, or perhaps emotional arousal"49 that create over time a powerful sense of having been present at an event of historical significance. ${ }^{50}$ They appear in all the multimedia adaptations of "Child, quickly grab hold of Mama's hand," thus constituting a powerful visual theme. This video finishes with a written message on the screen dedicating the poem to the PLA troops, police, medical personnel and "patriotic people" who helped with earthquake rescue efforts, and to Premier Wen Jiabao, who "persisted on the frontline of the disaster despite his advanced years." We also find out who produced it (“blue jingyu 鲸鱼” - blue whale - and a "Mr Dabao 大包” or Mr Bale) and are given a contact email address. We are not told who wrote the poem itself.

A second type of adaptation is almost the same as the first, except the poem is sung rather than recited. I have identified two pop songs and the score for one other musical adaptation..${ }^{51}$ One was written and performed by a singer-songwriter from Fujian province called Jiang Zhou 蒋舟. It appears online in at least two versions with the same audio recording but different visuals. One of these two versions is visually similar to the adaptation described above, featuring almost identical photos of the immediate aftermath of the quake. Interestingly, Jiang Zhou is listed as the author of the words as well as the music. The text is, in fact, more or less the same as the poem by Su Shansheng, with a few minor changes, such as use of repetition to make the lyrics scan better, the addition or deletion of the odd character like "no" (bu 不) or "also" (ye 也), and the exchange of "incomplete exam papers" in place of "Papa's fists" as something the child will no longer have to suffer. The video ends with cartoon images of children, and a request to the audience to light candles to "comfort injured hearts." 52

A second musical version of the song appears in many different versions online. The music is said to be composed by a songwriter called Wu Mengqi 吴梦奇 and has been recorded by the singer Zhou Yu 周渔. A year after being posted online, the version sung by Zhou had been played over one-and-a-half million times on one website alone, attracting around 12,000 comments, including an exclamation that it is "the most moving song I have ever heard!". ${ }^{53}$ Like Jiang Zhou's adaptation, it features a typical Chinese pop melody with a slow, uneven tempo, long phrases, and a gentle piano and string accompaniment. The music grows in volume and instrumentation a third of the way through

49 Roger Brown and James Kulik, "Flashbulb memories" (abstract), http://www.sciencedirect.com/science? _ob=ArticleURL\&_udi=B6T24-46632T5-6\&_user=10\&_rdoc=1\&_fmt $=$ \&_orig=search\&_sort $=\mathrm{d} \&$ view $=$ c\&_acct $=C 000050221 \& \_v e r s i o n=1 \& \_u r l V e r s i o n=0 \& \_u s e r i d=10 \& \mathrm{md} 5=3 \mathrm{da} 84 \mathrm{f} 1 \mathrm{fc} 1 \mathrm{c} 2 \mathrm{da}$ $603 \mathrm{c} 0934 \mathrm{ce} 8 \mathrm{e} 7 \mathrm{e} 8997$.

50 Barbara Kirschenblatt-Gimblett, "Kodak moments, flashbulb memories: reflections on 9/11," The Drama Review, Vol. 47, No. 1 (2003), pp. 11-48.

51 The sheet music for a different musical version, apparently written on 24 May 2008 and with Hong Weiguo cited as the author of the words, can be found at: http://www.gangqinpu.com/html/5421.htm.

52 http://you.video.sina.com.cn/b/13929168-1349202150.html.

53 http://v.youku.com/v_show/id_cb00XMjgwMjkxNDQ=.html. 
with the introduction of drums, bass and backing vocals. The final section drops back down to piano and vocals, before the video finishes with a photo of a child holding its mother's hand, and the names of the song's composers and performer. The author of the lyrics is stated to be a "web friend."

A third type of adaptation can be found in videos recorded from television broadcasts of recited and sung versions of the poem, copied from television to computer (sometimes via a handheld video recorder pointed at the screen), ${ }^{54}$ and then uploaded on to the internet. One example is a recital of the poem on a Dragon TV (Dongfang weishi 东方卫视) news programme, presented by $\mathrm{Yu}$ Dan 于丹 and Luo Xin 骆新. It begins with an emotional Yu discussing the aftermath of the earthquake and her personal reaction to the tragedy. A minute in, Luo mentions that he and $\mathrm{Yu}$ recently received a text message containing the poem "Child, quickly grab hold of Mama's hand." He proceeds to take out his phone, search for the poem and recite it live on air. The camera zooms in for a close-up of Yu Dan's face, with tears rolling down her cheeks. By the end both presenters are crying, and the rest of the video shows them discussing their inability to contribute towards earthquake relief efforts beyond the sum of money they have already donated. Some viewers have remarked that the real reason Yu Dan is crying is because she donated so little (100,000 yuan) compared to her huge annual earnings as a best-selling author and media celebrity, but others have cited such video clips as their first exposure to the poem, and claimed that the sight of $\mathrm{Yu}$ and Luo's tears was immensely moving. ${ }^{55}$ Worth noting here are the multiple stages of technological mediation on display: the poem has travelled from internet forum via email, blogs and text message to a mobile phone, recited in a television recording studio, broadcast on television, then recorded on to a computer and posted back to the internet, all in the space of less than a week.

Other televised recitals of the poem were more staged, employing professional actors, stage lighting and musical accompaniment. One example, shown on Dragon TV as part of a fundraising programme, was recited by the actress $\mathrm{Xi}$ Meijuan 奚美娟 and an eight-year-old girl called Li Jiayi 李嘉仪. The names of the actors and of the poem are given, but the author of the poem is not. This recital takes its cues from poems found in the first category in its choice of musical accompaniment, use of an adult and child narrator, and in the vocal cadences towards the poem's denouement, slowing and rising in volume. Other features are more medium-specific: that it was recorded in front of a live studio audience might explain why Xi Meijuan appears to improvise upon the words in places, slightly changing the text of the poem, and why it incorporates theatrical moments, such as when the actors walk across the stage and hold hands to recite the final section of the poem in unison.

54 See the following video for an example: http://www.youtube.com/watch?v=Csmjm38IRac\& feature $=$ related.

55 See the comments section, http://blog.sina.com.cn/s/blog_5labadbe01009e5h.html. 
A fourth type of adaptation can be identified in commercially produced music videos of the poem. In June 2008 a group of 50 Hong Kong pop singers recorded a Band Aid-style music video for the song version composed by Wu Mengqi. It begins like many other multimedia adaptations with a photograph of strong visual impact: a clock with its hands permanently pointing to $2.28 \mathrm{pm}$, the precise time the quake hit. Smoke rises from the bottom of the screen as the picture fades out and then in again to moving video footage of the singers in a recording studio, hands over headphones, singing into their microphones as the lyrics scroll across the bottom of the screen. Photographs of the earthquake are interspersed with video recorded in the studio. Backing vocals riff on individual lines, and the poem is stretched into a song that lasts nearly five minutes. Opening credits list the lyricist as anonymous (yiming 佚名), even though $\mathrm{Su}$ Shansheng had long been identified as the poem's author by most media outlets. The closing credits, on the other hand, are exhaustive, listing the names of the songwriter, singers, producers, recording studio, vocal coach, sound mixers, vocal producer, design company, record company and so on. This commercial musical adaptation is clearly the furthest removed from its origins as a linear text poem composed as an impromptu response to the earthquake by a Chinese netizen. At the same time, the anonymity of the song's lyricist suggests an attempt on the part of the video's producers to emphasize the authenticity of its emotional message.

A pared-down celebrity performance of this arrangement was sung live at the eleventh anniversary celebrations of Hong Kong's handover to the PRC on 30 June 2008, broadcast on TVB Jade. ${ }^{56}$ This anniversary is usually marked with a combination of celebrations and protests, the latter organized by campaigners for democracy and economic and media freedoms. ${ }^{57}$ The Sichuan earthquake imbued the anniversary with extra significance, allowing the organizers of the televised celebrations to promote an image of solidarity during a period of mourning that was observed by Chinese people regardless of location or nationality. ${ }^{58}$ This was arguably the most striking example of how the Chinese government and the mass media were able to appropriate "Child, quickly grab hold of Mama's hand" in order to fulfil certain key narratives regarding the nature of the Chinese people's collective response to a national catastrophe like the Sichuan earthquake. Once again, by emphasizing the anonymity or ordinariness of the poem's author, the media implicitly underlined the phenomenon of spontaneous popular grief that in China finds expression through the historically important and culturally refined medium of poetry. The inclusion of a sung version of the poem at the handover anniversary concert might be said to reflect the

56 http://www.youtube.com/watch?v=ZiJSPsjAyPg.

57 Keith Bradsher, "Hong Kong marks anniversary of handover," New York Times, 1 July 2007, http:/l www.nytimes.com/2007/07/01/world/asia/01iht-hong.1.6431824.html.

58 People in Hong Kong gave generously to earthquake relief funds, suggesting this image of solidarity was more than just media propaganda. According to the Hong Kong Red Cross, over HK\$1.27 billion was received in charitable donations by November 2008. Cf. http://www.redcross.org.hk/china_earthquake/ eng/. 
Chinese government's desire to highlight and encourage an emergent sense of Pan-Chineseness or "Cultural China," in which events that affect the well-being of the Chinese people are felt as keenly in China's Special Administrative Regions, would-be provinces and overseas communities as they are within the mainland itself. 59

\section{Conclusion: Quake Poetry as Convergence Culture}

Rather than being a collective, populist response by Chinese netizens to national tragedy, as many media accounts suggested, the multimedia adaptations of Quake Poems described above were the product of a convergence of interests (cultural, political and personal), individuals, institutions and media technologies. They can, in other words, be seen to represent a kind of convergence culture that is intricately related to the political and socio-cultural circumstances of contemporary China. Henry Jenkins's term "convergence culture" is itself a convergence of the three concepts of media convergence, participatory culture and collective intelligence. ${ }^{60}$ It refers not just to a process of technological development in which multiple media functions are brought together within the same devices and content is spread across different media, but represents a broader cultural shift, whereby audiences are taking an increasingly active, participatory approach to culture and media content. ${ }^{61}$ On a basic level, the creation and proliferation of multimedia Quake Poetry suggests the need for a more fan- (or in this case, netizen-) focused approach to understanding contemporary culture, one that acknowledges overlaps between producers and consumers, and seeks to unravel the potential of collective intelligence enabled by new media. ${ }^{62}$

The multimedia adaptations of "Child, quickly grab hold of Mama's hand" that were circulated online, broadcast on television and performed live at events such as the eleventh anniversary Hong Kong handover celebrations were based upon an original cultural text produced by an apparently "ordinary" Chinese netizen, who was acting wholly independently of commercial or institutional affiliations. The challenges involved in tracing the identity of the poem's author highlight how quickly the poem had developed into a malleable, collectively elaborated cluster of texts, yet also how the notion of individual creative agency continues to hold sway among consumers. Research into the implications of media convergence and participatory culture for different areas of contemporary Chinese culture is still at an early stage. How might trends in cultural production described by Jenkins and others, and evidenced in this case by the rapid

59 For more on the Chinese government's interest in Pan-Chinese nationalism see Guo Yingjie, Cultural Nationalism in Contemporary China: The Search for National Identity Under Reform (London \& New York: Routledge, 2004).

60 Henry Jenkins, Convergence Culture: Where Old and New Media Collide (New York: New York University Press, 2006), p. 2.

61 Ibid. p. 3.

62 The term "collective intelligence," as used by Jenkins and others, is taken from Pierre Lévy, Collective Intelligence: Mankind's Emerging World in Cyberspace (Cambridge, MA: Perseus Books, 1997). 
popularization of Quake Poetry, affect our understanding of the relationship between media, the online masses and the Chinese state? And more specifically, what do such waves of netizen-produced poetry mean for contemporary China's avant-garde poetry scene, which is theoretically open to the possibility of "grassroots" writing, yet often guarded when it comes to gaining access to individual poetry communities or "live scenes" (xianchang 现场) of contemporary poetry?63 These questions await further exploration.

Another question that requires consideration here is: why was it poetry that Chinese netizens turned to first in the wake of the Sichuan earthquake? A practical answer might be that poetry is the shortest of literary genres, and can be produced with a minimum of expertise, time and resources. It is also conducive to rapid circulation via copy-and-pasting or electronic forwarding, and can be easily memorized and recited. More significantly, poetry in China possesses a long tradition of being composed to commemorate significant events, in particular in the form of elegies to mourn the deaths of loved ones (daowang shi 悼亡诗). ${ }^{64}$ In this sense, the "prosumers" of Quake Poetry were participating in a literary tradition that far precedes the advent of new media technologies. Cultural precedent, as Michel Hockx and Yang Guobin have argued, is in fact an essential element in the development of internet culture. ${ }^{65}$ Many online cultural forms, such as online literary magazines, have their roots in pre-existing artistic genres and media of circulation. If multimedia poetry, like the examples of Quake Poetry adaptations investigated in this article, is to be viewed as an emergent part of China's ever-developing internet culture, then it cannot be understood independently of China's poetic tradition.

It is, furthermore, important to remember that the appropriation of netizenpenned Quake Poetry by the Chinese mass media - and by association the government - also has its own historical precedent. From the "going to the people" (dao minjian qu 到民间去) movement of the May Fourth era (1910s-1920s), through Mao's demands of artists and writers to adapt folk culture to serve the needs of the communist revolution (spelled out in his Yan'an talks in 1942), to the Multimillion Poem Movement of the Great Leap Forward (195861), and even down to the inclusion of traditional folksongs on popular television shows such as Super Girl (Chaoji nüsheng 超级女声) in 2004-06, Chinese intellectuals, the mass media and the state have time and again looked to "ordinary people" for creative inspiration and ideological support. ${ }^{66}$ "Web friends" and

63 For more on the functioning and discourses of the contemporary Chinese poetry scene see Heather Inwood, "On the scene of contemporary Chinese poetry," PhD dissertation, SOAS, 2008.

64 Cf. Hilde de Weerdt, "Grief for departed women in Shi from Jin to Sui," Papers on Chinese Literature, No. 1 (1993), pp. 21-39.

65 Michel Hockx, "Links with the past: mainland China's online literary communities," Journal of Contemporary China, Vol. 13, No. 38 (2004), pp. 105-27, and Yang Guobin, "The internet as cultural form."

66 For an overview of uses of folk culture by Chinese intellectuals in the Republican era see Chang-tai Hung, Going to the People: Chinese Intellectuals and Folk Literature, 1918-1937 (Cambridge, MA: Harvard University Press, 1985). 
"netizens" could be seen as the latest terms to be added to a lexicon that includes “among the people," “popular" or “folk” (minjian 民间, pingmin 平民 or minzhong 民众), “mass” or “the masses” (qunzhong 群众 or dazhong 大众), and "the People" (renmin 人民).

China's netizens, however, are not always as willing to be subsumed by the ideology of the Chinese state as the mass media's appropriation of Quake Poetry might seem to suggest. On the one hand, the broadcasting of "Child, quickly grab hold of Mama's hand" on national television implies that China's leadership had recognized the gains to be had in encouraging this form of emotional catharsis. The repeated images of mourning, of "Grandpa" Wen Jiabao visiting the affected earthquake zone, ${ }^{67}$ of parental grief and organized charity events that were featured in multimedia adaptations of Quake Poetry bolstered the image of Chinese unity and national strength that the CCP has been intent on promoting since the 1980s. ${ }^{68}$ As Yu Haiqing asserts, cultural appropriation of the kind examined in this article is part of the ruling elite's strategy to reclaim ideological legitimacy in the eyes of the Chinese public during the country's shift from a socialist to a capitalist political and economic system. ${ }^{69}$ Although more recently the authorities have proceeded to crack down on netizen-activists' attempts to investigate the numbers of deaths caused by the earthquake and the reasons for the collapse of so many schools, ${ }^{70}$ in the immediate aftermath of the earthquake poems like "Child ..." appeared to be functioning in strong support of the government's nation-building goals.

On the other hand, netizen-produced culture tends to be dominated more by an atmosphere of "carnival, community and contention"71 than of ideological harmony, with netizen interests often appearing in contrast, or even opposition, to those of the state. The use of human flesh searches to investigate instances of official corruption or social injustice, the proliferation of web-slang designed to circumvent or poke fun at government censorship (such as "river crab" hexie 河蟹 used as a homonym for harmony/censorship hexie 和谐), ${ }^{72}$ and the continued popularity of online spoofs ( $e^{\prime} g a o$ 恶搞) as a means of challenging state authority and internet control all demonstrate that Chinese internet culture - and the online Chinese public - is nowhere near as "harmonious" as the government wishes it were. ${ }^{73}$

67 Chris Buckley, “'Grandpa Wen' comforts China’s earthquake victims,” http://uk.reuters.com/article/ idUKPEK20190120080514.

68 Karsten Giese, "Speaker's corner or virtual panopticon: discursive construction of Chinese identities online," in Francoise Mengin (ed.), Cyber China: Reshaping National Identities in the Age of Information (New York: Palgrave Macmillan, 2004), pp. 19-36.

69 Yu Haiqing, Media and Cultural Transformation in China, p. 152.

70 Cf. Simon Elegant, "A year after Sichuan quake, citizens press for answers," Time Magazine, 12 May 2009, http://www.time.com/time/world/article/0,8599,1897567,00.html, and Tania Branigan, "China jails investigator into Sichuan earthquake schools," The Guardian, 9 February 2010, http://www. guardian.co.uk/world/2010/feb/09/china-eathquake-schools-activist-jailed.

71 Yang Guobin, The Power of the Internet in China: Citizen Activism Online (New York: Columbia University Press: 2009), p. 1.

72 For a list of current Chinese web slang see http://www.chinasmack.com/glossary.

$73 \mathrm{Hu}$ Ge's most recent (2010) online video, "Apartment dwellers" (Zhaiju dongwu) simultaneously 
Quake Poetry is notable for demonstrating what appears to be a high degree of creative consensus and emotional cohesion among its prosumers, as well as for the speed with which the internet, mobile communications technologies and other mass media enabled these poems to reach the screens and minds of Chinese citizens worldwide. Media convergence and ongoing transformations in Chinese society have contributed towards an internet culture of which Quake Poetry is just one part, a culture that has been accurately described by $\mathrm{Yu}$ Haiqing as "consumerist, propagandistic, artistic, performative, deliberate and spontaneous."74 Multimedia Quake Poetry stands as testament to the complex relationship between the Chinese people, the media they employ to create and consume culture, Chinese cultural traditions, and the state. This article has proposed that this poetry, despite being widely described as a vernacular, populist phenomenon, was in fact deeply implicated in the ideological agenda of the Chinese government, acting through the convergence of a broad network of people, technologies and media platforms.

\title{
Appendix: Chinese Version of "Child, Quickly Grab Hold of Mama's Hand"
}

\author{
孩子, 快 \\ 抓紧妈妈的手 \\ 去天堂的路 \\ 太黑了 \\ 妈妈怕你 \\ 碰了头 \\ 快 \\ 抓紧妈妈的手 \\ 让妈妈陪你走 \\ 妈妈 \\ 怕 \\ 天堂的路 \\ 太黑 \\ 我看不见你的手 \\ 自从 \\ 倒塌的墙 \\ 把阳光夺走 \\ 我再也看不见 \\ 你柔情的眸 \\ 孩子 \\ 你走吧 \\ 前面的路
}

footnote continued

parodies the nature programme "Animal world" (Dongwu shijie) and government censorship of the internet. See http://www.youtube.com/watch?v=R2n5GoGWmb0.

74 Yu Haiqing, Media and Cultural Transformation in China, p. 152. 
950 The China Quarterly, 208, December 2011, pp. 932-950

\author{
再也没有忧愁 \\ 没有读不完的课本 \\ 和爸爸的拳头 \\ 你要记住 \\ 我和爸爸的摸样 \\ 来生还要一起走 \\ 妈妈 \\ 别担忧 \\ 天堂的路有 些挤 \\ 有很多同学朋友 \\ 我们说 \\ 不哭 \\ 哪一个人的妈妈都是我们的妈妈 \\ 哪一个孩子都是妈妈的孩子 \\ 没有我的日子 \\ 你把爱给活的孩子吧 \\ 妈妈 \\ 你别哭 \\ 泪光照亮不了 \\ 我们的路 \\ 让我们自己 \\ 慢慢的走 \\ 妈妈 \\ 我会记住你和爸爸的模样 \\ 记住我们的约定 \\ 来生一起走
}

